\author{
Alenka TEMELJOTOV SALAJ \\ Ajda FOŠNER \\ Jerneja JURCA \\ Irena KARČNIK \\ Irena RAZPOTNIK \\ Lidija DOVGAN ŽVEGLA
}

\title{
Znanja, veščine in kompetence za urejanje prostora
}

Skladno s tehnološkim in z znanstvenim napredkom ter vse večjo kompleksnostjo družbenih procesov se je tudi na področju urejanja prostora pojavila potreba po interdisciplinarnosti znanj, veščin in kompetenc posameznika. Proces urejanja prostora namreč vključuje potrebo po poznavanju različnih strokovnih in znanstvenih področij, od bolj umetniško usmerjenih, prek socioloških do popolnoma inženirsko-tehničnih vej in ekonomsko-pravnih področij. Tako mora posameznik znanja, ki jih pridobi med študijem, za svoje uspešno delo dopolniti in nadgraditi tudi s številnimi veščinami in kompetencami. Da bi prepoznale te in določile njihovo pomembnost, smo izvedle anketo med strokovnjaki, ki se ukvarjajo z obravnavanim področjem v Republiki Sloveniji. Rezultati ankete nam ponujajo vpogled $\mathrm{v}$ spekter področij, ki jih morajo ti strokovnjaki poznati, njihove specifične kompetence, prirojene in pridobljene veščine in probleme, s katerimi se srečujejo pri svojem delu. Le v povezavi različnih disciplin lahko pričakujemo uspešno rešitev problemov. Na mejnih področjih različnih ved namreč nastajajo nova znanja in spoznanja, ki omogočajo oblikovanje novih strokovnih in znanstvenih rešitev.

Ključne besede: urejanje prostora, interdisciplinarnost, znanja, veščine, kompetence 


\section{Uvod}

Z uvedbo novega študijskega programa tretje stopnje na Evropski pravni fakulteti v Novi Gorici, smer Pravo in management nepremičnin, v študijskem letu 2008/09 se je izkazalo, da je interdisciplinarna zasnova študijskega programa pritegnila $\mathrm{k}$ vpisu različne poklicne profile, ki so imeli zelo različno dodiplomsko izobrazbeno strukturo: od pravnikov, ekonomistov, gradbenikov, strojnikov, arhitektov, politologov do prometnih inženirjev. Dejstvo, da je stična točka med vsemi navedenimi poklicnimi področji, kadar se srečujejo na področju nepremičnin, prav poznavanje zakonitosti urejanja prostora, smo avtorice vzele za izhodišče članka.

Urejanje prostora je več med seboj usklajenih in dogovorjenih ukrepov glede gospodarjenja s prostorom in uravnavanja družbeno-ekonomskega razvoja. Cilj urejanja je čim boljše poznavanje in upoštevanje naravnih razmer, ekonomskega in socialnega razvoja. Pri tem je treba upoštevati tudi zastavljene cilje širše skupnosti (Stanič, 1997). Končni namen procesa je določiti zasnovo organizacije prostora. $S$ tem namenom se na lokalni ravni opredeljujejo namenska raba prostora, kriteriji in pogoji za spreminjanje namenske rabe ali za nove posege v prostor. Pri tem se poskuša oblikovati estetska podoba naselja, varovati krajinske značilnosti ter naravno in kulturno dediščino. Večina zakonodaje v Republiki Sloveniji in drugod zato pri urejanju prostora zahteva presoje vplivov na okolje ter ocene degradiranja urbane in krajinske podobe. Proces urejanja prostora mora torej vključevati različna znanstvena področja, od arhitekture, ki načrtuje in usklajuje podobo grajenih enot $\mathrm{v}$ naselju, geografije, ki preučuje razvoj in strukturo mest, značilnosti in funkcije mest ter povezanost s širšim zaledjem, krajinske arhitekture, ki načrtuje, varuje in razvija naravne sestavine mesta, sociologije, ki preučuje prebivalstvo, njegova gibanja in skupnosti, življenje v mestih, ekologije, ki skrbi za varstvo narave, okolja in prebivalstva $\mathrm{z}$ vidika sonaravnosti, varovanja zdravja in neoviranega razvoja, urbane ekonomije, ki obravnava gospodarske osnove življenja v mestih ter pogoje za gospodarske in storitvene dejavnosti, urbanizma in urbanističnega načrtovanja, ki zagotavljata pripravo delnih in celovitih urbanističnih zasnov ter izdelavo načrtov za razvoj in gradnjo mest in naselij, do drugih tehničnih strok, ki zagotavljajo usklajeno gradnjo vseh potrebnih tehničnih objektov za razvoj in delovanje mest in naselij. Vsa področja skupaj usklajujejo, načrtujejo in urejajo razvoj mest in naselij (internet 1). Urejanje prostora ob kompleksnosti današnjih procesov prodira torej že na toliko področij, da je težko prepoznati njegovo osnovno obliko. Je tak strokovnjak predvsem arhitekt, znanstvenik, sociolog, politolog, psiholog, pravnik ali kaj drugega, kot se sprašuje tudi Pogačnik (2006), je odprto vprašanje. Glede na to, da je ustvarjanje okolja, v katerem živimo, povezano $s$ kulturo, širjenjem vrednot, z zgodovino in $s$ spoštovanjem skupnih korenin, je tudi odgovor nanj toliko pomembnejši. Z raziskavo smo poskušale predvsem pridobiti informacije o znanjih, veščinah in kompetencah, ki jih potrebujejo strokovnjaki za urejanje prostora.

\section{Teoretična izhodišča}

V Nemčiji je razvoj izobraževalnega sistema na področju študija nepremičnin in prostorskega načrtovanja zaživel že veliko prej kot pri nas, z ustanovitvijo prve nepremičninske akademije univerze Regensburg leta 1990 (internet 2). Še dlje v zgodovino seže angleška $A$ theory of civil planing, delo pionirja teorije prostorskega načrtovanja Patricka Abercrombija iz leta 1933 (Streich, 2005). Tudi Evropski Svet za urbanizem je na konferenci o izobraževanju v Viseju na Portugalskem maja 2004 na temo poučevanja za arhitekturo in urbanizem $\mathrm{v}$ globalizaciji strnil diskusije z vizijo izobraževanja v petih točkah (Parham, 2004). Kot prvo je navedel priporočilo, da naj bi izobraževanje težilo $\mathrm{k}$ študiju preteklosti, zgodovine in korenin, ne samo $\mathrm{k}$ spodbujanju izvirnosti. Inovacije naj temeljijo na predhodnih izkušnjah, namesto da začenjamo vedno znova. Zato morajo študentje usvojiti določena znanja, jih analizirati ter doumeti interakcijo arhitekture in družbenega dogajanja. Študij naj bo zasnovan interdisciplinarno, od poznavanja arhitekture, urbanizma do številnih drugih ved. Naučiti se je treba kvantiteto podrediti kakovosti. In na zadnje, študentom je treba priučiti zavest, kako močno orožje je risba in kako moč vidne percepcije uporabljati modro.

Glaser idr. (2003) ugotavljajo, da je do enakih sklepov prišel tudi Thomas Krüger, profesor za projektni menedžment na delovnem področju mestne gradnje in prostorskega četrtnega načrtovanja tehnične univerze Hamburg - Harburg. Avtorji navajajo, da je Krüger v nekem intervjuju poudaril pomembnost razširitve področja prostorskega načrtovanja:

\footnotetext{
Zgodovinsko predstavlja prvi stolpec projektnega menedžmenta gradnja mest s koreninami v arhitekturi in krajinskem načrtovanju. Drugi stolpec predstavlja infrastrukturne in zakonite naloge mestnega in prostorskega načrtovanja. Tretji, novi stolpec, zajame teme, kot so razvijanje konceptov in učinkovitosti, vodenje in moderiranje, usmerjanje udeležencem in izvajanje procesov; to pomeni, da je treba povezati inženirske, organizacijske in ekonomske pristope. Menim, da je takšna substančna dopolnitev kompetenčnega profila prostorskega planerja $k$ projektnemu menedžerju ali projektnemu razvijalcu za različne kontekste smiselna in nujno potrebna. (Prav tam: 6.)
}

Enake ugotovitve so razvidne tudi iz raziskave mnenja diplomantov o učinkovitosti študija geodezije na Fakulteti za gradbeništvo in geodezijo Univerze v Ljubljani iz leta 2005 (glej Drobne idr., 2006), v kateri so ugotovili, da bi morali študentje na področju geodezije med študijem poleg ozke usmerjenosti v stroko pridobiti tudi interdisciplinarna znanja (ekonomija, 
pravo, javna uprava, komunikologija, organizacijske vede in podobno), ki so prav tako pomembna za delo v praksi.

Vse to nas je pripeljalo do oblikovanja prve hipoteze: za uspešno delo posameznika na področju urejanja prostora je pomembnejše osnovno poznavanje širokega, interdisciplinarnega spektra znanj kot poglobljeno, detajlistično poznavanje posameznega področja. Z zavedanjem pomembnosti obvladovanja širokega nabora potrebnih znanj za prostorsko načrtovanje $\mathrm{v}$ tujini so se širili tudi ponudniki študijskih programov, ki so vsak posebej zagotavljali optimalno razmerje znanja za optimalne dosežke v praksi. Združenje mestnega, regionalnega in krajinskega načrtovanja v Berlinu je v ta namen izdalo strokovne smernice za akreditacijo študijskih programov prostorskega načrtovanja. V njih so opredeljeni splošni cilji izobraževanja, med katere spadajo tudi te sposobnosti in kompetence (Schäfer, 2002):

- prostorska in socialna občutljivost ter tudi sposobnost ocenjevanja spreminjajočih se pojavov med zgrajenim okoljem in družbo v procesu njenega spreminjanja;

- celostno razmišljanje, ki mrežno povezuje različne ekonomske, socialne, kulturne in ekološke pozicije $\mathrm{v}$ družbi pri hkratnem upoštevanju zakonskih okvirov;

- ustvarjalne kompetence in estetska občutjivost, $s$ pomočjo katerih se lahko zaznajo in v pozitivni smeri nadaljujejo razvojne linije tradicionalno bogate in visoko razvite mestne kulture in regionalne identitete. Sposobnost prepoznave tako detajlov celote kot tudi celote, sestavljene iz skupine elementov, ima pri tem pomembno vlogo;

- komunikacijske kompetence, ki pomenijo sposobnost podajanja kompleksnih okoliščin, spoznanj in idej ter dosego nekonfliktnega konsenza med različnimi sektorskimi cilji in zahtevami;

- postopkovne kompetence, ki omogočajo implementacijo in uresničitev oblikovanih predlogov in rešitev v vsakdanjem življenju.

Za uspešno delo na katerem koli strokovnem področju, tako tudi na področju urejanja prostora, mora torej strokovnjak za obvladovanje hitrega tempa sprememb poleg znanj, pridobljenih v okviru organiziranega izobraževalnega sistema, obvladati tudi različne kompetence in veščine. Kompetence, znanje in veščine so tri dimenzije, $s$ katerimi lahko opišemo celostni intelektualni kapital (internet 3). Povezava med znanjem posameznika in znanjem družbe so mentalni modeli, ki nastanejo kot sinteza izkušenj in spoznanja. Tako so kompetence kompleksen sistem - gre za kombinacijo klasičnega (konceptualnega) znanja in veščin (operativnega znanja).

Vprašanje definicije znanja je bilo zanimivo že v zgodovini. Poenostavljeno definicijo pojma znanja, ki bi nam pomagala doreči potreben in zaželen proces pridobivanja potrebnih vsebin med izobraževalnim procesom in vzporedno neformalno nadgradnjo, se lahko omeji na dva tipa: strokovno in tehnično znanje ter izkušnje posameznika. Za strokovno in tehnično znanje je značilno, da se ga da pridobiti v izobraževalnem procesu, posameznik ga z nekaj motivacije lahko pridobi v določenem časovnem obdobju in je nujno potrebno za uspešno delo, saj brez tega znanja preprosto ni mogoče doseči rezultatov. Vendar pa to znanje ni dovolj za odlične rezultate. Drugo komponento uspešnosti tvorijo izkušnje, ki jih ni bilo mogoče pridobiti v klasičnem procesu izobraževanja. Izkušnje so vezane na praktične dogodke, v katerih je posameznik na svoji koži prepoznal, katere strategije so bolj učinkovite in katere manj. Misel, ki lepo predstavi osnovno značilnost izkušnje, je: »Izkušnja ni to, kar se ti zgodi, temveč je to, kar narediš s tem, kar se ti zgodi.« (Internet 4.)

Veščine prinesejo strukturo v strokovno znanje. Ne glede na to, za kakšno dejavnost gre, je posameznik, ki ima določeno veščino, sposoben znanje razvrstiti v logično zaporedje korakov, ki jim mora slediti, če želi priti do cilja in doseči uspeh. Za veščine je značilno, da posameznik, ki obvlada določeno veščino, pozna postopek in uporablja svoje znanje skladno s tem postopkom. Posameznik se z obvladovanjem veščine izogne naključnim napakam in poskusom ter ve, kako priti do cilja. Veščine se lahko prenesejo z ene osebe na drugo in jih lahko dogradimo prek procesa usposabljanja ali z individualnim usposabljanjem. $Z$ veščinami tako izboljšamo delovno uspešnost posameznika, z njimi lahko vsaj povprečno obvladamo določeno nalogo.

Kompetence pomenijo zmožnost skupne uporabe znanj, sposobnosti in veščin posameznika za uspešno izvedbo delovnih nalog. Služijo kot osnova za pripravo standardov ravni znanj in sposobnosti, ki jih mora imeti posameznik za uspešno opravljanje določenega dela. Poleg specialističnih znanj posameznika sestoji podlaga kompetenc še iz motivacije, sposobnosti, značajskih potez, vrednot, interesov in veščin. Model kompetenc je zbirka kompetenc, ki skupno definira uspešno delovanje posameznikov na določenih delovnih mestih in določa, katera znanja, sposobnosti in veščine so pomembni pri posameznikih za uspešno opravljanje nalog.

Osnovne mednarodne smernice podpore razvoju znanja, spretnosti in veščn $\mathrm{v}$ vsem procesu pridobivanja teh so sprejeti sklepi Sveta in predstavnikov vlad držav članic EU, ki so se sestali v okviru Sveta na temo vloge razvoja spretnosti in veščin pri spodbujanju ciljev Lizbonske strategije (glej Sklepi Sveta in predstavnikov vlad ..., Ur. l. EU, št. C 292/2005). V teh sklepih, sprejetih na eni strani na podlagi sklepov Sveta iz leta 2005 o osredotočenju na rast in nova delovna mesta s poudarkom na znanju, inovacijah in človeškem kapitalu ter na vseživljenjskem učenju kot osnovnem pogoju za dosego teh ciljev ter na dru- 
gi strani smernic za rast in zaposlovanje Lizbonske strategije (2005-2008), je poudarjeno, da spretnosti in veščine zajemajo niz rezultatov vseh oblik in ravni učenja. Razvoj spretnosti in veščin je najpomembnejši element strategij za vseživljenjsko učenje. Te morajo vključevati pridobivanje najpomembnejših veščin in temeljiti na učinkovitih, splošnih sistemih izobraževanja in usposabljanja, iz katerih izhajajo posamezniki, ki si vse življenje želijo obnavljati in razvijati svoje spretnosti in veščine. Zaradi spoznanj o pomembnosti in raznolikosti kompetenc ter z njimi povezanih prirojenih in pridobljenih veščin posameznika pri urejanju prostora v tujini smo za raziskavo tega področja pri nas postavile našo drugo hipotezo: Za uspešno delo posameznika na področju urejanja prostora so pomembnejše pridobljene oziroma priučene veščine kot prirojene veščine.

\section{Metoda dela}

Raziskava je bila izpeljana s pomočjo anketnega vprašalnika. Njen namen je bilo pridobiti informacije o znanstvenih področjih, $s$ katerimi se dnevno srečujejo strokovnjaki za urejanje prostora, poznavanju zakonodajnih predpisov pri njihovem delu, pomembnosti posedovanja določenih specifičnih kompetenc, prirojenih in priučenih veščin posameznika pri njegovem delu. Po Glynis Breakwell idr. (1995) gre torej za presečni tip ankete, enkratno anketiranje, cilj je bilo primerjati različne skupine $\mathrm{v}$ populaciji. Vprašalnik, ki smo ga poslale anketirancem v izpolnitev, obsega osem vprašanj. Dve vprašanji od osmih sta odprtega tipa, preostalih šest je prilagojenih načelom Likertove lestvice (Hafner Fink, 2004). Pomembnost vprašanja se ocenjuje na skali od 1 do 5 , pri čemer pomeni 1 sploh ne (najmanj pomembno), 5 pa zelopomembno (najpomembnejše). Prvo vprašanje tako obsega opredelitev pomembnosti poznavanja različnih področij, s katerimi se dnevno srečuje strokovnjak za urejanje prostora. $\mathrm{V}$ drugem vprašanju prepoznavamo pomembnost poznavanja zakonskih predpisov pri delu strokovnjaka za urejanje prostora. Tretje vprašanje zajema vprašanja, povezana $s$ kompetencami, ki so pomembne pri delu na področju urejanja prostora. Pri četrtem vprašanju smo ugotavljale pomembnost posameznih dejavnikov urejanja prostora za delo strokovnjakov na njihovem delovnem področju. Odgovori na prva štiri vprašanja bodo torej potrdili ali ovrgli našo prvo delovno hipotezo. Sodelujoči v raziskavi bodo pri šestem in sedmem vprašanju določali pomembnost določenim prirojenim in priučenim veščinam. Odgovori na omenjeni vprašanji bodo torej temelj za potrditev druge hipoteze oziroma nam bodo dali možnost, da bomo ovrgle drugo hipotezo.

Kot ciljne skupine pri raziskavi smo določile zaposlene v občinskih upravah in upravnih enotah na oddelkih za okolje in prostor, občinske urbaniste, zavode, inštitute, ki se ukvarjajo s področjem urejanja prostora, ter zasebna podjetja, ki opravljajo omenjeno dejavnost. Pri vzorčenju smo torej uporabile tehniko vzorčenja klastrov - naključno smo vzorčile znotraj več skupin, v vzorec pa smo vzele celo skupino (Fendre, 2008). Po elektronsko izvedeni anketi smo od 376 poslanih vprašalnikov prejele 109 izpolnjenih vprašalnikov, od tega 23 vprašalnikov oziroma $21 \%$ s strani upravnih enot, 25 vprašalnikov oziroma $23 \%$ s strani podjetij, ki se ukvarjajo z urejanjem prostora ter 61 vprašalnikov oziroma $56 \%$ s strani zaposlenih na občinskih upravah. Izpolnjene vprašalnike smo obravnavale kot vzorec, ki pomeni 29-odstotni odziv ciljne skupine. Vzorec je reprezentativen, ker njegove karakteristike ustrezajo karakteristikam populacije, saj smo $\mathrm{v}$ anketo zajele upravne enote in občine $\mathrm{v}$ Sloveniji ter večino podjetij, ki se ukvarjajo z urejanjem prostora.

Rezultati ankete za prva štiri vprašanja so predstavljeni na podlagi seštevka vrednosti, ki so jih anketiranci dodelili posameznemu indikatorju, ter primerjave teh glede na seštevek vrednosti, ki so jih vsi anketiranci dodelili vsem indikatorjem. Tako dobljena vrednost je bila v tortnih grafikonih prikazana kot odstotna zastopanost posameznega indikatorja glede na celoto (100 \%), ki smo ga raziskovale po posameznih anketnih vprašanjih. Pri šestem in sedmem vprašanju so rezultati predstavljeni le v histogramih kot aritmetične sredine za vsak posamezen indikator in ločeno glede na tip organizacije, iz teh pa je izračunana ponderirana oziroma tehtana aritmetična sredina. $S$ ciljem dodatne utemeljitve dobljenih rezultatov smo vzorec kvantitativno opredelile še glede na tip organizacije, $v$ kateri so anketiranci zaposleni. Izračunale smo aritmetične sredine posameznih odgovorov anketirancev na zastavljena vprašanja, ločeno glede na tip organizacije, upravne enote, občine in podjetja. Pri odprtih tipih vprašanj smo v rezultatih povzele največkrat omenjene probleme, s katerimi se srečujejo pri delu strokovnjaki za urejanje prostora, in največkrat omenjene komentarje na oceno izobraževalnega procesa, v okviru katerega so pridobili izobrazbo.

\section{Rezultati in razprava}

\subsection{Področja, s katerimi se pri svojem delu najpogosteje srečujejo strokovnjaki za urejanje prostora}

Anketiranci so pri prvem od postavljenih vprašanj ocenjevali, kako pomembna so področja, kot so arhitektura, urbanizem, krajinska arhitektura, kulturna dediščina, geodezija, geografija, geologija, evidentiranje nepremičnin, arheologija, gradbeništvo, komunalna infrastruktura, energetika, promet in zveze, pravo, ekonomija, menedžment, psihologija, sociologija, strojništvo in ekologija, pri njihovem delu. 
Iz rezultatov ankete je razvidno, da pri pomembnosti posameznih področij ni bistvenih razlik, ugotovljeno pa je bilo, da je za anketirance pri njihovem delu najpomembnejše poznavanje področij urbanizma (7,1 \% skupnega števila dodeljenih točk pri vprašanju), sledita področji komunalne infrastrukture $(6,8 \%)$ in gradbeništva $(6,5 \%)$, manjše razlike v pomembnosti so bile dodeljene področjem arhitekture in ekologije (vsako po $6,0 \%)$, prava $(5,8 \%)$ ter prometa in zvez $(5,8 \%)$. Med ostalimi 13 področji so minimalne razlike (skupaj 1,5\%): področja kulturne dediščine (5,5\%), energetike (5,4\%), geodezije $(5,1 \%)$, krajinske arhitekture in evidentiranja nepremičnin (vsako po 5,0 \%). Kot najmanj pomembna so bila označena področja ekonomija in menedžment (vsako po 4,2\%), strojništvo (3,1 \%), arheologija (3,3\%), geologija $(3,7 \%)$, sociologija $(3,7 \%)$, geografija $(3,8 \%)$ in psihologija $(4,0 \%)$. Glede na zaposlitve anketirancev pa so zaposleni na upravnih enotah kot najpomembnejša področja pri svojem delu ocenili (vrednost aritmetične sredine odgovorov nad 3,5) ta področja: komunalna infrastruktura $(4,4)$, pravo $(4,3)$, gradbeništvo $(4,2)$, urbanizem $(4,2)$, arhitektura $(4,0)$ in ekologija (vrednost 3,8). Zaposleni na občinah so po pomembnosti posameznih strokovnih področij najvišje ocenili komunalno infrastrukturo $(4,1)$ ter urbanizem $(4,0)$ in gradbeništvo $(3,8)$. Strokovnjaki iz podjetij so najvišje ocenili ta področja: urbanizem $(4,3)$, arhitektura $(3,7)$, ekologija $(3,6)$ in komunalna infrastruktura $(3,5)$. Odgovori med posameznimi strokovnjaki se pomembno razlikujejo v oceni pomembnosti področij: pravo (upravne enote 4,3, občine 3,2 in podjetja 3,0 ) in evidentiranje nepremičnin (upravne enote 3,2 , občine 3,1 in podjetja 2,1 ). Tudi pri ocenah ostalih področij so opazne minimalne razlike, ki pa statistično niso pomembne.

\subsection{Pomembnost poznavanja področij zakonodaje}

Pri drugem vprašanju so anketiranci ocenjevali pomembnost poznavanja različnih predpisov za svoje delo. Vrednotili so pomembnost poznavanja gradbene zakonodaje, okoljske zakonodaje, stanovanjskega zakona, zakonodaje o varstvu potrošnikov, občinskih odlokov, sistema prostorskega načrtovanja, nepremičninske zakonodaje, zakonodaje s področja urejanja prometa in sistema standardizacije.

Po odgovorih na drugo vprašanje lahko rezultate razdelimo na rezultate, ki so dosegli nad 13,0 \% odgovorov, in tiste, ki so zastopani z manj odstotki. Najpomembnejši sta po mnenju anketirancev poznavanje gradbene zakonodaje (13,8 \% skupnega števila vseh dodeljenih točk pri vprašanju) in poznavanje občinskih odlokov (13,7 \%), tesno sledita še poznavanje zakonodaje s področja prostorskega načrtovanja $(13,4 \%)$ in okoljske zakonodaje (13,1\%). Pod 13,0 \% so bila ovrednotena področja zakonodaje s področja urejanja prometa (11,3 \%), nepremičninske zakonodaje (10,2 \%), stanovanjskega zakona (9,4\%), sistema standardizacije (8,3\%). Najnižje je označena pomembnost poznavanja zakonodaje o varstvu potrošnikov $(6,8 \%)$. Pomembnost poznavanja posameznega predpisa anketiranci ocenjujejo zelo podobno, ne glede na svojo zaposlitev, razlike je sicer mogoče opaziti pri odgovorih glede poznavanja stanovanjske zakonodaje in nepremičninske zakonodaje, vendar statistično niso pomembne.

\subsection{Najpomembnejše posebne kompetence za uspešno delo}

Tretje vprašanje $\mathrm{v}$ anketi je predvidevalo opredelitev najpomembnejših kompetenc, pomembnih za uspešno delo strokovnjaka na področju urejanja prostora. $V$ anketi smo opredelile posamezne kompetence, ki izhajajo iz katalogov znanj posameznih univerz oziroma izobraževanja s področja prostorskega načrtovanja, kot so na primer seznanjenost z zgodovino urbanizma, seznanjenost s tipologijo naselij, poznavanje hierarhične strukture naselij, poznavanje vrste infrastrukture in urbane opreme glede na tip naselja, poznavanje pomena namenske rabe prostora in delitve funkcionalnih površin v mestih, uporaba tehničnih pogojev in priporočil za izgradnjo infrastrukture in urbane opreme v mestih, poznavanje dejavnikov urbanega razvoja, razumevanje ekologije ter razumevanje trajnostnega razvoja (internet 5 in 6).

Razlika med odgovori na tretje vprašanje je majhna, saj znaša razlika v deležih med prvo in zadnje uvrščenim odgovorom le $3 \%$ (maksimalno 12,3\%, minimalno 9,3\%). Kot najpomembnejša kompetenca se je pri analizi pridobljenih odgovorov izkazalo poznavanje pomena namenske rabe prostora in delitve funkcionalnih površin v mestih (12,3 \% vseh dodeljenih točk pri vprašanju), sledita še splošno razumevanje trajnostnega razvoja (obe 11,6\%) in seznanjenost s tipologijo naselij (11,5\%). Tesno skupaj so razporejeni še vsi drugi odgovori - poznavanje dejavnikov urbanega razvoja $(11,4 \%)$, poznavanje vrste infrastrukture in urbane opreme glede na tip naselja (11,3\%), razumevanje ekologije (11,0\%), uporaba tehničnih pogojev in priporočil za izgradnjo infrastrukture in urbane opreme $\mathrm{v}$ mestih in poznavanje hierarhične strukture naselij (obe po 10,8 \%). Kot najmanj pomembna je označena seznanjenost z zgodovino urbanizma (9,3\%). Posamezni kompetenci anketiranci pripisujejo približno enako pomembnost, iz česar izhaja, da strokovnjaki v občinskih upravah, upravnih enotah in podjetjih pri svojem delu potrebujejo enak nabor kompetenc.

\subsection{Najpomembnejši dejavniki pri delu}

Pri četrtem vprašanju ankete smo želele izvedeti, kateri dejavniki urejanja prostora so najpomembnejši pri delu anketirancev. Ovrednotiti je bilo treba devet različnih dejavnikov, kot so 
povezanost zakonodaje z urbanistično-arhitektonskimi načeli in usmeritvami, omejitveni dejavniki v prostorskem razvoju, različne težnje in potrebe v prostoru ter nasprotja med njimi, vloga socializacijskih in psiholoških elementov, pomen urbanističnega načrtovanja za ustvarjanje kakovostnih pogojev dela in bivanja, estetski osebnostni kriteriji in vizualizacijske spretnosti, vloga ekonomskih dejavnikov in vloga okoljskih dejavnikov pri urejanju prostora.

Iz rezultatov ankete lahko ponovno ugotovimo minimalne razlike med posameznimi odgovori. Pri obravnavanem vprašanju znaša razlika med prvo- in zadnjeuvrščenim dejavnikom 2,7 \% (maksimalno 12,2\%, minimalno 9,4\%). Tokrat so anketirani najvišje ovrednotili dejavnik povezanost zakonodaje $\mathrm{z}$ urbanistično-arhitektonskimi načeli in usmeritvami $(12,2 \%$ vseh dodeljenih točk pri vprašanju), tesno mu sledi pomen urbanističnega načrtovanja za ustvarjanje kakovostnih pogojev dela in bivanja z 12,1\%. Kot tretji najpomembnejši dejavnik pa so ovrednoteni omejitveni dejavniki v prostorskem razvoju $(12,0 \%)$. Sledijo vloga okoljskih dejavnikov pri urejanju prostora $(11,7 \%)$, spremembe v prostoru, ki so posledica različnih rab prostora $(11,5 \%)$, različne težnje in potrebe v prostoru ter nasprotja med njimi (11,3\%), vloga ekonomskih dejavnikov $(10,0 \%)$, vloga socializacijskih in psiholoških elementov $(9,8 \%)$ in estetski osebnostni kriteriji in vizualizacijske spretnosti (9.4\%). Tudi pri ocenjevanju pomembnosti dejavnikov pri urejanju prostora so si bili anketiranci iz občinskih uprav, upravnih enot in podjetij dokaj enotni glede pomembnosti posameznega dejavnika.

Iz analize prvih štirih vprašanj je razvidno, da lahko potrdimo svojo prvo hipotezo, ki smo jo postavile pred začetkom raziskovanja. Iz rezultatov je namreč očitno, da je pri delu posameznikov na področju urejanja prostora pomembnejše poznavanje širokega nabora znanj z različnih področij, torej interdisciplinarnost, ki se kaže v razpršeni porazdelitvi odstotkov med indikatorji v posameznem vprašanju, pred poglobljenim detajlističnim poznavanjem ozkega spektra znanj na ozko opredeljenih področjih.

Do podobnih rezultatov, kot so predstavljeni zgoraj, so prišli tudi mnogi drugi raziskovalci. Iz članka Henninga Frsa (1962) je razvidno, da prav delovne prakse posameznikov, ki se navezujejo na različne znanstvene discipline, pomenijo raziskovalcem izziv za interdisciplinarno delo. Enake sklepe je predstavil tudi Jurij Režek (2004: 93): »/.../ [V] postmoderni družbi je povečana potreba po povezovanju in sodelovanju več strok na področju urejanja prostora in preživeto je mišljenje, da je ena stroka zmožna in sposobna obvladovati vsa sodobna dogajanja v prostoru. « Interdisciplinarnost se razlikuje od multidisciplinarnosti, ki pomeni predvsem sodelovanje različnih področij, ki pri posameznih problemih med seboj sodelujejo, vendar ostajajo v okvirih in metodah svojih disciplin. Interdisciplinarnost se v nasprotju z multidisciplinarnostjo umešča $\mathrm{v}$ prostor med posameznimi disciplinami in pomeni sintezo znanj, ob čemer se dojemanje posameznih pojavov zaradi nove perspektive spremeni (Petts, 2008). Pri tem bi omenile tudi $\gg$ transdisciplinarnost «, kar ni niti interdisciplinarnost (presečna mešanica ločenih disciplin) niti multidisciplinarnost (mnogo ločenih posameznih disciplin) in pomeni potrebo, da se vzpostavi posebna akademska disciplina, kar je v tujini tako in tako že dolgo. Le pri nas je ujeta $\mathrm{v}$ okvire ustaljenih akademskih disciplin.

Uveljavljene metode in teorije matičnih disciplin so ena največjih ovir za interdisciplinarnost dela (Frs, 1962). Tako Hugh Petrie (1976) predlaga, da bi medsebojno razumevanje pridobili $s$ tem, da bi se posamezni raziskovalci naučili opazovalnih konceptov drugih vključenih disciplin. Interdisciplinarnost namreč teži k združevanju znanj posameznih področij (Ramadier, 2004, navedeno v Petts 2008). Tudi iz raziskave, opisane v članku Vanesse Castán Broto idr. (2009), izhaja, da so sodelujoči v raziskavi ugotovili, da so z interdisciplinarnim pristopom svojo kariero nadgradili ter tako obogatili svoje osebno in poklicno življenje.

Izobrazba s področja določene discipline omogoča raziskovalcem svobodno opravljanje interdisciplinarnih raziskovanj, saj ta ne morejo obstajati brez disciplin. Cilj interdisciplinarnega raziskovanja ne prinaša razdvajanja med posameznimi disciplinami, pač pa povzroča premikanje meja med posameznimi disciplinami. Pri interdisciplinarnem delu se srečujemo z mejnimi problemi, zato je ustvarjanje in delo v takih pogojih mogoče le $\mathrm{v}$ poznavanju, kje so te meje postavljene. Tako lahko interdisciplinarno raziskovanje uspešno deluje samo s prepletanjem disciplin oziroma morajo posamezniki, ki delajo v interdsciplinarnih timih razumeti in poznati osnovne principe vseh disciplin, ki so zastopane v timu (Castán Broto idr., 2009). Različne discipline so se v akademskih krogih tako dolgo ohranile samo zato, ker služijo kot priročna omejitev glede tega, $s$ čimer naj se posamezna akademska panoga ukvarja (Bruce idr., 2004), in ker je delovanje v okviru več disciplin veliko napornejše (Evans in Marvin, 2004). Kljub zapletenosti, ki jo prinaša interdisciplinarno delo, se vsi raziskovalci na koncu strinjajo, da so rezultati takšnega dela boljši, vendar pa za uspeh navajajo ključne pogoje, kot so medsebojno zaupanje med udeleženci interdisciplinarnega dela, vzajemno spoštovanje različnih disciplin in njihovih omejitev, potrebna priložnost za izmenjavo znanj in možnost za pogajanja na stičnih točkah različnih disciplin in priznavanje, da se problemi lahko rešujejo po različnih poteh (Petts idr., 2008).

Na podlagi številnih raziskav in diskusij lahko sklepamo, da na področju prostorskega urejanja resnično potrebujemo vključe- 
vanje širokega nabora znanj, disciplin in virov. Splošno interdisciplinarni pristop lahko opredelimo kot prednost.

\subsection{Najpogostejši problemi in omejitve pri delu}

Peto vprašanje anketnega vprašalnika je zastavljeno kot vprašanje odprtega tipa vprašanj, pri katerem lahko posamezniki dodajo svoje komentarje, pripombe in izkušnje iz prakse v zvezi $s$ problemi in z omejitvami, s katerimi se srečujejo pri svojem delu. $\mathrm{Za}$ analizo smo uporabile največkrat omenjene probleme in komentarje.

Najbolj poudarjeni in najizrazitejši pripombi anketirancev sta se nanašali na nestrokovnost vplivov dnevne politike in kapitala na urejanje prostora. Enako visoko so ocenili tudi probleme z neusklajenimi, zastarelimi in s slabo pripravljenimi prostorskimi akti. To je posledica prevelikega števila majhnih občin, ki ne zmorejo opraviti vseh nalog, ki jim jih nalaga zakonodaja. Premajhna oziroma neustrezna je tudi strokovnost oseb, ki se ukvarjajo s področjem urejanja prostora, in premalo je sredstev za naročanje strokovno izdelanih prostorskih dokumentov. Oteževalna okoliščina je vsekakor tudi prehitro spreminjanje zakonodaje ter neusklajena in nedorečena področna zakonodaja. Poznavanje zakonodaje v projektantski stroki anketiranci ocenjujejo kot slabo, hkrati zahteve investitorjev niso strokovne in niso usklajene $\mathrm{z}$ omejitvenimi dejavniki v prostoru. $\mathrm{Ni}$ zavedanja o pomenu varstva okolja in upoštevanja varovalnih ureditev. Uzaveščenost javnosti ocenjujejo kot nezadostno. Dodatne probleme povzročajo dolgotrajni upravni postopki, neurejena lastniška razmerja, nedokončani denacionalizacijski postopki in neživljenjski razlastitveni postopki. Manjka tudi vizija trajnostnega razvoja.

\subsection{Priučene veščine, potrebne za uspešno delo}

Cilj šestega vprašanja je bil ugotoviti, katere od naštetih priučenih veščin so pomembne za uspešno delo na področju urejanja prostora. Kot najpomembnejše priučene veščine, ki so dosegle vrednost aritmetične sredine nad 4,00 pri vseh tipih organizacij, se izkažejo delavnost, presojanje, timska usmerjenost, analitičnost, organiziranost, javno nastopanje in ciljna usmerjenost, vendar pa so tudi pri šestem vprašanju razlike v rezultatih minimalne. Najnižje so anketiranci ovrednotili empatijo in splošni menedžment. Ponderirana aritmetična sredina vseh dodeljenih vrednosti temu vprašanju na lestvici od $1-5$ pa je 3,93 , s tem da posameznim priučenim veščinam anketiranci ne glede na zaposlitev, pripisujejo približno enako pomembnost.

\subsection{Prirojene veščine, potrebne za uspešno delo}

Pri sedmem vprašanju zaprtega tipa smo želele ugotoviti, katere prirojene veščine so najpomembnejše za uspešno delo. $V$ vpra- šanju smo opredelile 10 prirojenih veščin, ki so jih anketiranci morali ovrednotiti. Iz rezultatov analize je razvidno, da so anketiranci najvišjo pomembnost pripisali veščinama natančnost in kreativnost, sledili so odločnost, vztrajnost in samozavest, ki so dosegle vrednost aritmetične sredine nad 4,0 pri vseh tipih organizacij. Najmanj pomembna prirojena veščina je po mnenju anketirancev dominantnost. Ponderirana oziroma tehtana aritmetična sredina vseh odgovorov, ocenjenih na lestvici od $1-5$, je 3,98. Vsem priučenim veščinam anketiranci ne glede na svojo zaposlitev pripisujejo približno enako pomembnost.

Rezultati šestega in sedmega vprašanja nam tako na podlagi izračuna razlike med ponderiranima aritmetičnima sredinama odgovorov omogočajo zavrnitev druge delovne hipoteze, saj je razlika med njima, minimalna. Tako lahko trdimo, da so za delo posameznika na področju urejanja prostora enako pomembne njegove priučene in prirojene veščine, kar je ovrglo našo drugo hipotezo. Tudi glede na tip organizacije, v kateri so anketiranci zaposleni, so ti posamezni priučeni in prirojeni veščini pripisali približno enako pomembnost. To dokazuje, da zaposlitev vključenih oseb ne vpliva na rezultate odgovorov.

Enake sklepe glede preučevanja novega urbanističnega načrtovanja na Japonskem navaja tudi Silke Vogt (2001). Sistem dejavnikov urbanističnega načrtovanja je tam sicer nekoliko drugače porazdeljen. Zajema različne sloje ljudi, znanstvenike in politike ter prebivalce, ki jih imenujejo » urbanistični laiki«, pri čemer so različne tudi njihove strokovne usposobljenosti in veščine. Kljub temu pa pridemo do skupnega stičišča - pri odločanju so enako pomembne vse veščine, tako pridobljene kot prirojene. Na kongresu »Impulskongres « so svoje mnenje o znanju in veščinah predstavili tudi strokovnjaki nemškega urbanističnega inštituta (2001: 5): »Obstaja poenoteno mišljenje, da naj bi četrtni menedžer, ki naj bi udejanjal vlogo prostorskega mestnega načrtovanja, po idealnih kriterijih znal vse, to pomeni, da se od njega pričakuje visoka stopnja socialnih, strokovnih, načrtovalnih, ekonomskih, menedžerskih, organizacijskih in komunikacijskih kompetenc, pri hkratnem upoštevanju lokalne politike. Od njega se pričakuje natančnost, vestnost in timska usmerjenost.«

Nadaljnje razprave so pokazale, da naj bi uspešen urbanist obvladoval ekonomski, socialni in urbanistični jezik. »Videnje celote in ne le lastnega strokovnega področja je ena bistvenih vrlin.« (Prav tam: 126.) Iz navedenega izhaja, da se rezultati nemške študije o pomembnosti različnih veščin popolnoma ujemajo z rezultati, dobljenimi pri naši raziskavi.

\subsection{Subjektivna ocena izobraževalnega procesa s strani anketirancev}

Zadnje vprašanje ankete je bilo odprtega tipa in je anketirancem dopuščalo možnost komentarjev in pripomb v zvezi z 
izobraževalnim procesom, v katerem so pridobili izobrazbo. Tudi tokrat smo za analizo izbrale le najpogostejše komentarje. Anketiranci procese, v katerih so pridobili svojo stopnjo izobrazbe, večinoma ocenjujejo pozitivno in menijo, da so jim dali dobre teoretične osnove, primerne za nadgradnjo pri nadaljnjem študiju ali praktičnem delu. Večina obenem meni, da ni dobila nobenih ali pa premalo praktičnih, aplikativnih znanj. Meni tudi, da bi ji študij moral ponuditi vsaj osnovno poznavanje področne zakonodaje in seznanitev z omejitvenimi dejavniki, ki imajo največji vpliv na delo pri urejanju prostora. Skoraj vsi udeleženci poudarjajo potrebo po bolj interdisciplinarni obliki študija na tem področju. Prav tako menijo, da bi morali programi bolj slediti spremembam in napredku tehnologije.

\section{Sklep}

Ugotovitve, do katerih smo prišle na podlagi metodološko izpeljane raziskave, so temeljile na podlagi anketnega vprašalnika, ki je obsegal osem vprašanj. Namen raziskave je bilo pridobiti informacije o znanstvenih področjih, $s$ katerimi se dnevno srečujejo strokovnjaki za urejanje prostora, poznavanju zakonodajnih predpisov pri njihovem delu, pomembnosti posedovanja določenih specifičnih kompetenc ter prirojenih in priučenih veščin, ki jih posameznik potrebuje pri svojem delu. Kot ciljne skupine za raziskavo smo, kot je bilo že omenjeno, določile zaposlene v občinskih upravah ter upravnih enotah na oddelkih za okolje in prostor, občinske urbaniste, zavode, inštitute, katerih zaposleni se ukvarjajo z urejanjem prostora, in zasebna podjetja, ki opravljajo omenjeno dejavnost.

Glede na analizo podatkov prvih štirih vprašanj ankete lahko $z$ gotovostjo trdimo in $s$ tem potrdimo našo prvo hipotezo, da je za uspešno delo na področju urejanja prostora pomembnejše poznavanje širokega spektra znanj z različnih področij kot poglobljeno detajlistično poznavanje ozkega spektra znanj na ozko opredeljenih področjih. Področja, $s$ katerimi se strokovnjaki za urejanje prostora najpogosteje srečujejo pri svojem delu, so urbanizem, komunalna infrastruktura, gradbeništvo, arhitektura in ekologija. Pri ocenjevanju pomembnosti poznavanja zakonodaje pri svojem delu so anketirali poudarili poznavanje gradbene zakonodaje, občinskih odlokov, zakonodaje s področja prostorskega načrtovanja in okoljske zakonodaje. Različne specifične kompetence, ki vplivajo na uspešnost dela, so anketiranci ovrednotili primerljivo, nobeni posamezni kompetenci niso pripisali opazno večjega pomena; kot najpomembnejši kompetenci so opredelili poznavanje pomena namenske rabe prostora in delitve funkcionalnih površin $\mathrm{v}$ mestih.
Drugo hipotezo lahko na podlagi rezultatov ankete ovržemo, saj so po mnenju anketirancev za uspešno delo posameznika na obravnavanem področju pomembne tako prirojene veščine kot pridobljene oziroma priučene veščine. Iz rezultatov šestega in sedmega vprašanja je namreč razvidna minimalna razlika med pomembnostjo priučenih veščin v razmerju do prirojenih veščin, zato lahko trdimo, da so oboje veščine enako pomembne za delo posameznika na področju urejanja prostora.

Za dodatno utemeljitev dobljenih rezultatov smo vzorec anketirancev kvantitativno opredelile še glede na tip organizacije, $v$ katerih so ti zaposleni. Ne glede na skupino iz vzorca oziroma zaposlitev anketirancev je bil dobljeni rezultat odgovorov primerljiv z odgovori celotnega vzorca.

Izvedena raziskava in njeni izsledki temeljijo na statistično reprezentativnem in veljavnem vzorcu in potrjujejo, da obstajata velika potreba in interes za pridobivanje širokega nabora znanj, veščin in kompetenc za potrebe dela na področju urejanja prostora. $\mathrm{Z}$ raziskavo se je tako potrdila potreba po interdisciplinarni zasnovi študijev na področju urejanja prostora, ki bi ob nadaljnji medsebojni komunikaciji in delovanju v širšem družbenem prostoru lahko povečala identiteto in razpoznavnost strokovnjakov s področja urejanja prostora. Končni cilj izobraževanja takih strokovnjakov je doseganje bolj kakovostnega razvoja $\mathrm{v}$ prostoru in $s$ tem povezanih boljsih življenjskih pogojev. Raziskavo bi bilo mogoče razširiti še na druge ciljne skupine, kot so inšpekcijske službe, področna ministrstva, študijske ustanove, geodetska stroka, nepremičninski posredniki in drugi strokovnjaki, saj je z urejanjem prostora povezanih veliko področij.

Alenka Temeljotov Salaj

Evropska pravna fakulteta v Novi Gorici, Nova Gorica, Slovenija

E-pošta: alenka.temeljotov-salaj@gea.college.si

\section{Ajda Fošner}

Evropska pravna fakulteta v Novi Gorici, Nova Gorica, Slovenija E-pošta: ajda.fosner@gea-college.si

Jerneja Jurca

Evropska pravna fakulteta v Novi Gorici, Nova Gorica, Slovenija E-pošta: jerneja.jurca@siol.net

Irena Karčnik

Evropska pravna fakulteta v Novi Gorici, Nova Gorica, Slovenija E- pošta: irena.karcnik@siol.net

Irena Razpotnik

Evropska pravna fakulteta v Novi Gorici, Nova Gorica, Slovenija E-pošta: janez.razpotnik@amis.net

Lidija Dovgan Žvegla

Evropska pravna fakulteta v Novi Gorici, Nova Gorica, Slovenija E-pošta: lidija.zvegla@siol.net 


\section{Zahvala}

Avtorice članka se iskreno zahvaljujemo vsem, ki so sodelovali pri anketni raziskavi, za strokovno pomoč pri nastajanju članka pa Kaliopi Dimitrovski-Andrews, Ivanu Staniču in Mojci Šašek Divjak.

\section{Viri in literatura}

Breakwell, M. G., Hammond S., in Fife-Schaw, C. (1995): Research methods in psychology. London, SAGE Publications Ltd.

Bruce, A., Lyall, C., Tait, J., in Williams, R. (2004): Interdisciplinary integration in Europe: the case of the Fifth Framework Programme. Futures, 36, str. 457-470.

Castán Broto, V., Gislason, M., in Ehlers, M. H. (2009): Practising interdisciplinarity in the interplay between disciplines: experiences of established researchers. Environmental Science \& Policy, 12, str. 922-933.

Drobne, S., Breznikar, A., in Babič, U. (2006): Mnenje diplomantov o učinkovitosti študija geodezije. Geodetski vestnik, 50(2), str. $270-286$

Evans, R., in Marvin, S. (2004): Disciplining the sustainable city: moving beyond science, technology or society. Dostopno na: http:// www.lse.ac.uk/collections/resurgentCity/Papers/marvinevans.pdf (sneto 19. 3. 2010).

Fendre., B. (2008): Čustvena inteligenca-pot do poslovne uspešnosti. Magistrsko delo. Ljubljana, Univerza v Ljubljani, Ekonomska fakulteta.

Frs, H. (1962): Institutional means of collaboration between the social sciences. Social Science Information, 1, str. 5-22.

Glaser, J., Pohlan, J., in Schlomka, B. (2003): Harburger Absolventen befragung 2003. Raum Planung, 110, str. 1-6.

Hafner Fink, M. (2004): Metodologija družboslovnega raziskovanja, Ljubljana, FDV.

Internet 1: http://www.slonep.net/pred-gradnjo/lokacija/ prostorsko-nacrtovanje/ (sneto 28. 8. 2009).

Internet 2: http://www.immobilienakademie.net/unser-unternehmen (sneto 10. 10. 2009).

Internet 3: http://www.mnovice.com/2009/03/

znanje-vescine-kompetence/ (sneto 9. 6. 2009).

Internet 4: http://www.moj-mentor.si/vescine-znanja-talenti.html (sneto 9. 6. 2009).

Internet 5: http//www.kamen.uni-mb.si/dokument.aspx?id=2215 (sneto 10. 10. 2009).

Internet 6: http//www.ecnm.si/dokumenti/vok/Urbanizem.pdf (sneto 10. 10. 2009).

Sklepi Sveta in predstavnikov vlad držav članic, ki so se sestali v okviru Sveta, o vlogi razvoja spretnosti in veščin pri spodbujanju ciljev Lizbonske strategije. Uradni list Evropske unije, št. C 292/02/2005. Luksemburg.

Nemški urbanistični inštitut (2001): Arbeitspapiere Band 5, Dokumentation des Impulskongress Quartiermanagement, Berlin. Dosto- pno na: http://www.difu.de/publikationen/2001/

soziale-stadt-impulskongress-quartiermanagement.html (sneto 21. 3. 2010).

Parham, S. (2004): A synthesis: New Strategies for Education in Architecture and Urbanism. Dostopno na: http://www.ceunet.org/ reportfromviseu.html (sneto 6. 9. 2009).

Petrie, H. G. (1976): Do you see what I see? The epistemology of interdisciplinary inquiry. Journal of Aesthetic Education, 10(1), str. 29-43.

Petts, J., Owens, S., in Bulkeley, H. (2008): Crossing boundaries: interdisciplinarity in the context of urban environments. Geoforum, 39(2), str. 593-601.

Pogačnik, A. (2006): Nagovor ob prejemu Fabianijeve nagrade. Geodetski vestnik, 50(4), str. 698-701.

Ramadier, T. (2004): Transdisciplinarity and its challenges: the case of urban studies. Futures, 36, str. 423-439.

Režek, J. (2004): Evolucija stroke in nova delovna področja geodezije. Geodetski vestnik, 48(1), str. 93-98.

Schäfer, R. (2002): Fachliche Standards für die Akkreditierung von Studiengängen der Stadtplanung, Raumplanung. Dostopno na: http:// www.srl.de/dateien/dokumente/de/fachliche_standards_fuer_die_ akkreditierung_von_studiengaengen_der_stadtplanung_ raumplanung_november_2002.pdf (sneto 10.10. 2009).

Stanič, I. (1997): Planiranje skozi komunikacijo. Urbani izziv, 30/31, str. 80-82.

Streich, B. (2005): Stadtplanung in der Wissensgesellschaft. Ein Handbuch. Wiesbaden, VS Verlag für Sozialwissenschaften.

Vogt, S. (2001): Neue Wege der Stadtplanung in Japan. Partizipationsansätze auf der Mikroebene, dargestellt anhand ausgewählter machizukuri-Projekte in Tokyo. München, ludicium Verlag GmbH. 